\title{
BEHAVIOR OF Angiostrongylus costaricensis IN PLANORBIDS
}

\author{
BANEVICIUS, N. M. S., ZANOTTI-MAGALHÃES, E. M., \\ MAGALHÃES, L. A. and LINHARES, A. X. \\ Departamento de Parasitologia, Instituto de Biologia, Universidade Estadual de Campinas, UNICAMP, \\ C. P. 6109, CEP 13083-970, Cidade Universitária, Barão Geraldo, Campinas, SP, Brazil \\ Correspondence to: Eliana Maria Zanotti-Magalhães, Departamento de Parasitologia, Instituto de Biologia, \\ Universidade Estadual de Campinas, UNICAMP, C. P. 6109, CEP 13083-970, \\ Cidade Universitária, Barão Geraldo, Campinas, SP, Brazil, e-mail: emzm@unicamp.br \\ Received June 7, 2004 - Accepted October 19, 2004 - Distributed February 28, 2006
}

\begin{abstract}
Some terrestrial mollusks are natural hosts of Angiostrongylus costaricensis. In the laboratory, this nematode can be maintained in certain planorbids, which are aquatic mollusks and intermediate hosts of Schistosoma mansoni. Mollusks can be infected with Angiostrongylus costaricensis by ingestion of or active penetration by the first-stage larvae. In this work we assessed the ability of Biomphalaria glabrata to attract first-stage larvae of A. costaricensis. Movement of the nematode larvae towards the mollusks was observed after $15 \mathrm{~min}, 30 \mathrm{~min}$ and $1 \mathrm{~h}$. B. glabrata did not attract the first-stage larvae of A. costaricensis in any of the three intervals. The susceptibility of two populations of Biomphalaria tenagophila to infection by A. costaricensis was also determined. One population was genetically selected for the susceptibility to $S$. mansoni while the other was not. Third-stage larvae were recovered from the snails 30 days after exposure of the two populations to 120 first-stage larvae. All the mollusks were infected. However, a significantly higher number of third-stage larvae were recovered in mollusks not genetically selected.
\end{abstract}

Keywords: Angiostrongylus costaricensis, Biomphalaria glabrata, Biomphalaria tenagophila.

\section{RESUMO}

\section{Comportamento do Angiostrongylus costaricensis em planorbídeos}

Alguns moluscos terrestres são hospedeiros naturais do Angiostrongylus costaricensis. No laboratório, esse nematódeo pode ser mantido em planorbídeos, que são moluscos aquáticos e hospedeiros intermediários do Schistosoma mansoni. Os moluscos podem ser infectados com A. costaricensis por ingestão ou por penetração ativa de larvas de primeiro estágio. Neste trabalho, testamos a habilidade de Biomphalaria glabrata em atrair larvas de primeiro estágio de A. costaricensis. A movimentação das larvas do nematódeo em direção aos moluscos foi observada após 15 minutos, 30 minutos e 1 hora. B. glabrata não atraiu as larvas de primeiro estágio de $A$. costaricensis nos três intervalos de tempo. Verificamos também a suscetibilidade de duas populações de Biomphalaria tenagophila à infecção por A. costaricensis. Uma população era selecionada geneticamente para a susceptibilidade ao $S$. mansoni, enquanto a outra não o era. Larvas de terceiro estágio foram recuperadas dos moluscos 30 dias após a exposição das duas populações a 120 larvas de primeiro estágio. Todos os moluscos estavam infectados. Entretanto, um número significativamente maior de larvas de terceiro estágio foi recuperado em moluscos não geneticamente selecionados.

Palavras-chave: Angiostrongylus costaricensis, Biomphalaria glabrata, Biomphalaria tenagophila. 


\section{INTRODUCTION}

The intermediate hosts of Angiostrongylus costaricensis are usually terrestrial pulmonate mollusks of the family Veronicellidae (slugs), particularly the genera Sarasinula (Thiengo, 1996) and Phyllocaulis (Graeff-Teixeira et al., 1989). However, other terrestrial mollusks such as Bradybaena similaris, Limax maxinus and Limax flavus have also been found to be naturally infected. A large number of mollusk species can be infected experimentally in the laboratory, thereby confirming the ability of the nematode to parasitize different intermediate hosts (Morera, 1988). The genera Megalobulinus (M. abreviatus) and Biomphalaria (B. glabrata, B. tenagophila, B. straminea) are also susceptible to $A$. costaricensis in the laboratory (Graeff-Teixeira et al., 1989; Lima et al., 1992). The susceptiblity of planorbids to infection by Schistosoma mansoni is a genetically controled and hereditary trait (Newton, 1952; Richards, 1970; Santana et al., 1978). Thus, populations of $B$. tengophila susceptible to $S$. mansoni have been obtained by selecting the progenies of selffertilized susceptible mollusks (Santana et al., 1978, Zanotti-Magalhães et al., 1991).

Kloetzel (1958) reported that miracidia of S. mansoni showed chemotropism for B. glabrata. Several substances present in snail conditioned water have been considered to be attractants for these miracidia, including fatty acids (MacInns, 1965), $\mathrm{H}^{+}$ions (MacInns, 1965), amino acids (Wright \& Ronald, 1972; MacInns et al., 1974; Prechel et al., 1976), serotonin (Etges et al., 1975), $\mathrm{Mg}^{2+}$ (Stibbs et al., 1976), ammonia (Manson, 1979), and peptin (Manson, 1979).

Thiengo (1996) and Mendonça et al., (1999) showed that, in addition to infecting Sarasinula marginata after ingestion, L1 larvae of A. costaricensis can also penetrate the tegument of the host during brief exposure to the parasite (30 min).

We used B. glabrata, a planorbid that is more susceptible to A. costaricensis (Lima et al., 1992), to assess whether larvae L1 of A. costaricensis were attracted to the mollusk in a manner similar to that reported for miracidia of $S$. mansoni. Since infection of the mollusks can also occur through penetration of L1 A. costaricensis, we considered the possibility that the mollusks may release an attractant or attractants for the larvae. If this proves to be the case, then there will be a greater possibility of finding B. glabrata or other freshwater snails infected with $A$. costaricensis in the wild.

In a second experiment, we examined whether $B$. tenagophila genetically selected for susceptibility to $S$. mansoni were also more susceptible to A. costaricensis than non-selected snails. This experiment was made to assess whether susceptibility to one species extended to others.

\section{MATERIAL AND METHODS}

Melanic specimens of B. glabrata from Belo Horizonte (MG, Brazil) and melanic samples of B. tenagophila from São José dos Campos (SP, Brazil), genetically selected or not selected for susceptibility to the $S$. mansoni, were kept in the laboratory at the Campinas State University Department of Parasitology and the $\mathrm{F}_{54}$ generation was used. The strain of $A$. costaricensis used here was isolated from Crissiumal (RS, Brazil). The L1 A. costaricensis were obtained from the feces of the rodent Sigmodon hispidus (Rodentia:Cricetidae) (cotton rat), using Rugai et al.'s method (1954). In the first experiment, each of three groups of 10 specimens of $B$. glabrata was exposed to $10 \mathrm{~L} 1$ for $15 \mathrm{~min}, 30 \mathrm{~min}$ and $1 \mathrm{~h}$. The behavior of the larvae in the presence of mollusks was verified using a glass apparatus, which consisted of two circular chambers $30 \mathrm{~mm}$ in diameter attached to a $40 \mathrm{~mm} \times 11 \mathrm{~mm}$ channel, as described by Brasio et al. (1985) for experiments with S. mansoni. The chambers were filled with chlorine-free water. In each experiment, $10 \mathrm{~B}$. glabrata were placed in one chamber (A) while the other (B) contained only chlorine-free water. The mollusks were approximately $8 \mathrm{~mm}$ in diameter. Using a stereoscopic microscope, $10 \mathrm{~L} 1$ were placed with a pipette in the center of the channel $(\mathrm{C})$ connecting the two chambers. The movement of the larvae was observed for $15 \mathrm{~min}, 30 \mathrm{~min}$ and $1 \mathrm{~h}$, and the number of L1 that migrated to each of the two chambers was recorded for each interval. Ten observations using 10 snails each were made for each time period, making a total of 30 snails. After each observation, the apparatus was washed to avoid any possible interference caused by mucus tracks and feces from the mollusks (Brasio et al., 1985). 
All the experiments were conducted under diffuse illumination with a $60 \mathrm{~W}$ incandescent lamp.

In the second experiment, 15 specimens of B. tenagophila genetically selected for susceptibility to $S$. mansoni and 20 non-selected snails, all with a diameter of $8-9 \mathrm{~mm}$, were placed individually in glass vials ( $30 \mathrm{~mm} \times 24 \mathrm{~mm}$ ) and exposed for $24 \mathrm{~h}$ to $120 \mathrm{~L} 1 \mathrm{~A}$. costaricensis collected from the feces of S. hispidus. After exposure, the L1 remaining in the vials were counted and the mollusks were then placed in individual $250 \mathrm{~mL}$ vials filled with chlorine-free water and containing lettuce ad libitum. Thirty days after the exposure, the soft parts of each mollusk were artificially digested, as described by Wallace \& Rosen (1969). The product of the digestion of each snail was placed in a $50 \mathrm{~mL}$ sedimentation cup for $4 \mathrm{~h}$ to recover the third-stage larvae (L3) of A. costaricensis. After decantation, $5 \mathrm{~mL}$ of solution from the bottom of each cup was pipetted onto a petri dish and the L $3 \mathrm{~A}$. costaricensis were counted with the aid of a stereoscopic microscope. During the 30 days that the mollusks were in the laboratory, two non-selected snails died of natural causes so their data were excluded from the final results.

A statistical analysis was made using the PROC GLM (general linear procedure) option of the $\mathrm{SAS}^{\circledR}$ (Statistical Analysis System) statistical package (SAS Institute, 1987). One-way was used to assess the susceptibility of $B$. tenagophila to A. costaricensis larvae. The factor in this analysis was the snail population, and the response was the frequency of larvae.

\section{RESULTS}

There was no attraction of $\mathrm{L} 1 \mathrm{~A}$. costaricensis to B. glabrata, regardless of the exposure time (Table 1). Tables 2 to 4 show the susceptibility of B. tenagophila to A. costaricensis. More L1 A. costaricensis were ingested by or penetrated genetically selected $B$. tenagophila than

TABLE 1

Percentage of L1 Angiostrongylus costaricensis in compartments A (B. glabrata), C (channel) and B (chlorine-free water).

\begin{tabular}{|c|c|c|c|}
\hline \multirow{2}{*}{ Time (minutes) } & \multicolumn{3}{|c|}{ L1 in the compartments (\%) } \\
\cline { 2 - 4 } & A & C & B \\
\hline 15 & 1 & 99 & 0 \\
\hline 30 & 4 & 95 & 2 \\
\hline 60 & 1 & 97 & 2 \\
\hline
\end{tabular}

TABLE 2

Mean number of infective L1 Angiostrongylus costaricensis in B. tenagophila genetically selected (S) or non-selected (NS) for susceptibility to $S$. mansoni.

\begin{tabular}{|c|c|c|c|}
\hline Duncan test* $^{*}$ & L1 & Number of mollusks & Mollusks \\
\hline A & 112.267 & 15 & $\mathrm{~S}$ \\
\hline B & 108.833 & 18 & NS \\
\hline
\end{tabular}

*Mean values with the same letter are not significantly different (overall error rate $(\alpha)=0.05$ ).

TABLE 3

Mean numbers of L3 Angiostrongylus costaricensis recovered in selected (S) and non-selected (NS) B. tenagophila 30 days after infection.

\begin{tabular}{|c|c|c|c|}
\hline Duncan test* & L3 & Number of mollusks & Mollusks \\
\hline A & 22.133 & 15 & S \\
\hline B & 40.389 & 18 & NS \\
\hline
\end{tabular}

*Mean values with the same letter are not significantly different (overall error rate $(\alpha)=0.05)$. 
TABLE 4

Difference between the mean numbers of L1 and L3 Angiostrongylus costaricensis in selected (S) and non-selected (NS) B. tenagophila.

\begin{tabular}{|c|c|c|c|}
\hline Duncan test* & L1-L3 & Number of mollusks & Mollusk \\
\hline A & 90.133 & 15 & S \\
\hline B & 68.444 & 18 & NS \\
\hline
\end{tabular}

*Mean values with the same letter are not significantly different (overall error rate $(\alpha)=0.05$ ).

non-seleceted snails $(\mathrm{F}=4.44 ; \mathrm{p}=0.0433)$. The number of L3 A. costaricensis that developed after 30 days was greater in non-selected B. tenagophila $(\mathrm{p}=0.0118)$ and the difference between the number of L1 ingested or that penetrated and the number of L3 that developed was also significant $(p=0.0049)$. This difference was greater in the selected mollusks, which were infected by more L1 but which yielded fewer L3. Duncan's multi-range test detected significant differences in L1 and L3, and in the difference between them (L1-L3).

\section{DISCUSSION}

The presence of a resistant cuticle, the longitudinal arrangement of the muscle fibers and the presence of celomatic liquid under positive pressure allow nematode larvae to move on solid substrates and to swim in liquid. Considering the short length of L1 A. costaricensis $(0.26-0.29 \mathrm{~mm})$ and the low frequency of undulating movements, the locomotive power of these larvae is sufficiently small to restrict their movement from one place to another. This behavior is characteristic of larvae living in soil or at the bottom of a liquid mass. In all the attraction experiments conducted here, the larvae remained at the bottom of the apparatus and their movements decreased over time, so that after $60 \mathrm{~min}$ they had become practically motionless. The hypothesis that L1 shows tropism towards B. glabrata was not confirmed by our results. In the three periods studied (15, 30 and $60 \mathrm{~min})$, most of the A. costaricensis larvae remained in channel $\mathrm{C}$, with no movement towards chamber A containing the mollusks (Table 1).

The immunological reactions of mollusks to parasitism by nematodes are poorly understand, although most nematodes that develop in gastropods produce a tissue reaction without actually killing the host (Lie et al., 1987). Nematodes are always encapsulated in the body of their hosts, and ultrastructural studies of capsules produced by A. cantonensis in B. glabrata indicate that they are induced mainly by granulocytes (Harris \& Cheng., 1975). These capsules do not have any noticeable harmful effect on the development of the parasites. Stewart et al. (1985) observed that in B. glabrata the encapsulation of $\mathrm{L} 1 A$. costaricenis was slower than that of A. cantonensis. Harris \& Cheng (1975) suggested that the failure of B. glabrata to kill the encapsulated larvae of A. cantonensis resulted from the insufficient release of lysosomal enzymes by hemocytes. Guaraldo et al., (1981) observed that B. tenagophila genetically selected for susceptibility to $S$. mansoni showed small reactions around the larvae of the trematode and the sporocysts developed normally.

The balance of the host-parasite relationship depends on the genetic background of the organisms involved, since this background conditions their physiological and metabolic capacity (Zanotti-Magalhães et al., 1997). In addition to environmental factors, the development of miracidia in the intermediate host depends on the genetic characteristics that lead to physiological adjustments between the infecting larvae and the mollusk (Machado et al., 1988). Although the B. tenagophila genetically selected for susceptibility to $S$. mansoni were infected by a larger number of L1 A. costaricensis, fewer L3 were recovered when compared with the population of non-selected mollusks. This finding may indicate the presence of factors that affect larval development. Since B. tenagophila were genetically selected for susceptibility to the SJ strain of $S$. mansoni through successive self-fertilizations of susceptible progenies, this could have made physiological adjustment more specific for $S$. mansoni relative to other strains of the trematode (Zanotti-Magalhães et al., 1997) 
and of some nematodes. The genetic selection of the intermediate host could have affected the host-parasite relationship, possibly causing the A. costaricensis larvae to become inefficient. In this case, encapsulation and phagocytosis by hemocytes, as well the release of enzymes could have been more efficient against the $A$. costaricensis larvae. This could explain the fewer L3 recovered. In nonselected B. tenagophila as well as in B. glabrata, the immunological system could have been less efficient, so that the encapsulated larvae did not die. Although the mollusks were infected with a smaller number of L1 A. costaricensis, a larger number of L3 was recovered. In conclusion, the genetic selection that occurred in B. tenagophila infected with $S$. mansoni SJ was not observed in B. tenagophila infected with A. costaricensis, since the latter developed better in non-genetically selected B. tenagophila.

\section{REFERENCES}

BRASiO, B. C., MAGAlhãES, L. A., Miller, J. \& CARVALHO, J. F., 1985, Atração de miracídios de Schistosoma mansoni por hospedeiros invertebrados. Comportamento de miracídios frente a girinos de Hyla fuscovaria. Rev. Saúde Pública S. Paulo, 19: 18-27.

ETGES, F. J., CARTER, O. S. \& WEBBE, G., 1975, Behavioral and development physiology of schistosoma larval as related to their molluscan hosts. Ann. N.Y. Acad. Sci., 266: 480-496.

GRAEFF-TEIXEIRA, C., THOMÉ, J. W., PINTO, S. C. C., CAMILO-COURA, L. \& LENZI, H. L., 1989, Phylliocaulis variegatus - an intermediate host of Angiostrongylus costaricensis in south Brazil. Mem. Inst. Oswaldo Cruz, 84: 65-68.

GUARALDO, A. M. A., MAGALHÃES, L. A., RANGEL, H. A. \& PAREJA, G., 1981, Evolução dos esporocistos de Schistosoma mansoni Sambon, 1907, em Biomphalaria glabrata (Say, 1818) e Biomphalaria tenagophila (D'Orbigny, 1835). Rev. Saúde Pública S. Paulo, 15: 436-448.

HARRIS, K. R. \& CHENG, T. C., 1975, The encapsulation process in Biomphalaria glabrata experimentally infected with the metastrongylid Angiostrongylus cantonensisi: enzyme histochemistry. J. Invert. Pathol., 26: 367-374.

KLOETZEL, K., 1958, Observações sobre o tropismo do miracídio do Schistosoma mansoni pelo molusco Australorbis glabratus. Rev. Bras. Biol., 18: 223-232.

LIE, K. L., JEONG, K. H. \& HEYNEMAN, D., 1987, Molluscan host reaction to helminthic infection. pp. 211-270. In: E. J. L. Soulsby (ed.). Immune Responses in Parasitic Infections: Immunology, Immunopathology and Immunopropyilaxis. Vol. IV: Protozoa, Arthropods and Invertebrates, Chapter 7, CRC Press, Florida.
LIMA, L. C., MASSARA, C. L., SOUZA, C. P., VIDIGAL, T. D., LENZI, H. L. \& CARVALHO, O. S., 1992, Suscetibilidade de planorbídeos da região metropolitana de Belo Horizonte, MG (Brasil) ao Angiostrongylus costaricensis (Nematoda, Angiostrongylidae). Rev. Inst. Med. Trop. São Paulo, 34: 399-402.

MACHADO, S. M. P., MAGALHÃES, L. A., ARTIGAS, P. T., CORDEIRO, N. S. \& CARVALHO, J. F., 1988. Verificação do antagonismo entre larvas de Schistosoma mansoni e larvas de outros Digenea em Biomphalaria tenagophila molusco planorbídeo de criadouro natural situado na região de Campinas, SP, Brasil. Rev. Saúde Pública S. Paulo, 22: 484-488.

MACINNS, A. J., 1965, Responses of Schistosoma mansoni miracidia to chemical attractants. J. Parasitol., 51: 731-746.

MACINNS, A. J., BETHEL, W. M. \& CORNFORD, E. M., 1974, Identification of chemicals of snail origin that attract Schistosoma mansoni miracidia. Nature, 248: 361-363.

MANSON, P. R., 1979. Amonia excretion by planorbid snails. A possible mechanism for host selection by schistosome miracidia. J. Parasitol., 65: 819-820.

MENDONÇA, C. L., CARVALHO, O. S., MOTA, E. M., PELAJO-MACHADO, M., CAPUTO, L. F. \& LENZI, H. L., 1999. Penetration sites and migratory routes of Angiostrongylus costaricensis in the experimental intermediate host (Sarasinula marginata). Mem. Inst. Oswaldo Cruz, 94: 549-556.

MORERA, P., 1988, Angiostrongilíase abdominal. Um problema de saúde pública. Rev. Soc. Bras. Med. Trop., 21: 81-83.

NEWTON, W. L., 1952, The comparative tissue reaction of two strains of Australorbis glabratus to infection with Schistosoma mansoni. J. Parasitol., 38: 362-366.

PRECHEL, D. P., CAIN, G. D. \& NOLLEN, P. M., 1976, Responses of Megalodiscus temperatus miracidia to amino and sialic acids found in the snail-conditioned water. J. Parasitol., 62: 693-697.

RICHARDS, C. S., 1970, Genetics of a molluscan vector of schistosomiasis. Nature, 227: 806-810.

RUGAI, E., MATTOS, T. \& BRISOLA, A. P., 1954, Nova técnica para isolar larvas e nematóides das fezes. Modificação da técnica de Baermann. Rev. Inst. Adolfo Lutz, 14: 5-8.

SANTANA, J. V., MAGALHÃES, L. A. \& RANGEL, H. A., 1978, Seleção de linhagens de Biomphalaria tenagophila e Biomphalaria glabrata visando maior suscetibilidade ao Schistosoma mansoni. Rev. Sáude Pública S. Paulo, 12: 67-77.

STEWART, G. L., UBELAKER, J. E. \& CURTIS, D., 1985, Pathophysiology alterations in Biomphalaria glabrata infected with Angiostrongylus costaricensis. J. Invert. Pathol., 45: 152-157.

STIBBS, H. H., CHERNIN, E., WARD, S. \& KARNOVSKY, M. L., 1976. Magnesium emitted by snails alters swimming behaviour of Schistosoma mansoni miracidia. Nature, 260: 702-703.

THIENGO, S. C., 1996, Mode of infection of Sarasinula marginata (Mollusca) with larvae of Angiostrongylus costaricensis (Nematoda). Mem. Inst. Oswaldo Cruz, 91: 277-278. 
WALLACE, G. D. \& ROSEN, L., 1969, Techniques for recovering and identifying of Angiostrongylus cantonensis from molluscs. Malacologia, 7: 427-438.

WRIGHT, D. G. S. \& RONALD, K., 1972, Effects of amino acids and light on the behavior of miracidia of Schistosomatium douthitti (Cort, 1914). Canad. J. Zool., 50: 855-860.

ZANOTTI-MAGAlHÃES, E. M., MAGAlHÃES, L. A. \& CARVALHO, J. F., 1991, Relação entre a patogenicidade do
Schistosoma mansoni em camundongos e a suscetibilidade do molusco vetor. I. Infecciosidade das cercárias e carga de vermes. Rev. Sáude Pública S. Paulo, 25: 399-402.

ZANOTTI-MAGALHÃES, E. M., MAGALHÃES, L. A. \& CARVALHO, J.F., 1997, Relação entre a patogenicidade do Schistosoma mansoni em camundongos e a suscetibilidade do molusco vetor. IV. Infecciosidade dos miracídios. Rev. Sáude Pública S. Paulo, 31: 488-494. 